\title{
Rheological evaluation of industrial tomato
}

\author{
Anna Rita Tóth - Mária Takácsné Hájos \\ University of Debrecen, Faculty of Agricultural and Food Sciences and Environmental Management \\ Institute of Horticultural Science \\ H-4032 Debrecen, Böszörményi Street 138. \\ toth.anna.rita@agr.unideb.hu
}

\begin{abstract}
SUMMARY
Today, tomato has the second largest harvesting area globally, and the fourth largest in Hungary. The importance of industrial tomato is growing year by year, and one of the most important tasks is to satisfy the needs of the industry. To meet these needs, the producer has to find the proper genotype, which can achieve up to $100 \mathrm{t} \mathrm{ha} \mathrm{h}^{-1}$ crop yield. This quality has high importance to be researched.

The experiment was carried out in the Botanical and Exhibition Garden of the University of Debrecen, with 3 examined genotypes. The planting date was 3 of May 2018. The harvesting was two-threaded. On 27 of July the physical parameters - fruit shape index (length/diameter), firmness $\left(\mathrm{kg} \mathrm{cm}^{-2}\right)$, water-soluble dry matter content (Brix\%) and weight of the berries $(\mathrm{g})$ - were evaluated. On 15 of August the rheological parameters were examined - the force needed to tear the skin-bioyield point $(g)$ and flesh firmness $(g)$.

The fruit shape index was oval (between 1.19 and 1.24) for all the examined genotypes. The firmness was between $0.92\left(U G 1122713 F_{1}\right)$ and 1.05 (Prestomech $\left.F_{1}\right) \mathrm{kg} \mathrm{cm}^{-2}$, which compliance the needs of the industry. The water-soluble dry matter content was suitable, with a value between 4.49 (Prestomech $\left.F_{1}\right)$ and $4.65\left(U G 1122713 F_{l}\right)$ Brix\%. The weight of the berries was between $45.94\left(U G 989 F_{1}\right)$ and 49.37 (Prestomech $F_{l}$ ) g per piece.

The bioyield point was between $76.00\left(U G 1122713 F_{1}\right)$ and $85.16\left(U G 989 F_{1}\right) \mathrm{g}$. The flesh firmness was between $33.68\left(U G 1122713 F_{1}\right)$ and $42.81\left(U G 989 F_{1}\right) g$.

Finally, we can conclude based on the obtained data that the UG989 $F_{1}$ hybrid was the most proper for the applied cultivation conditions. This genotype can be recommended for the farmers even in extreme weather conditions.
\end{abstract}

Keywords: industrial tomato, rheological evaluation, tomato genotypes

\section{INTRODUCTION}

Tomato (Lycopersicon lycopersicum L.) belongs to the Solanaceae family. The species originated in Central America. It was brought to Europe by the Spanish conquistadors in the $15^{\text {th }}$ century. The first written records about tomato were found in Italy and dated back to 1544 . Two centuries passed before it became widespread in the continent, the first record that said it is edible only date back to 1710 (Helyes, 1999).

Nowadays it is the second most important vegetable crop after onion with 4.8 million ha of area harvested worldwide (FAO, 2018). Its importance is outstanding not only worldwide, but also in Hungary.

In Hungary the total production area of tomato was 2500 ha (KSH, 2018) including 1800-2000 ha of industrial tomato, which is nearly $80 \%$ of the total area (I1). The production was more than $100,000 \mathrm{t}$, and in the next 2-3 years more expansion is expected. All of the produced tomato is processed by Hungarian factories (Univer) (Rimóczi, 2018).

There are many reports about the qualitative evaluation of agricultural products (Arana, Jarén and Arazuri, 2004; Jarén and García, 2002; Peris, 1983). In the case of industrial tomato, concrete specifications are demanded by the industry (Calvo, 1996). Because most quality factors are related to physical properties in most of the cases it is possible to develop quality evaluation methods based on these properties (Ruiz and Chen, 1990).
One of the most important quality parameters is firmness (Wu and Abbott, 2001), which is an index of the mechanical, chemical and rheological properties of the fruit (Vursavus and Kesilmis, 2016). Different methods exist to examine this parameter, such as the Magness-Taylor test (Plocharski et al., 2000), or rheological evaluation of flesh firmness.

The skin resistance (bioyield point) is closely linked with firmness. It is very important during transportation, because cracks in the skin allows the juice to flow out, and damaged berries can easily become rotten (Arazuri et al., 2006). According to previous reports, the most common technique to measure skin resistance was puncture test (Catala et al., 1982). Another important parameter that defines the quality of tomato is the water-soluble dry matter content. The widely used method to determine this parameter is refractometry (Arazuri et al., 2006).

The main purpose of the experiment was to find the most proper genotype for industrial growing even in extreme weather conditions.

\section{MATERIAL AND METHODS}

The experiment was conducted in the Botanical and Exhibition Garden of the University of Debrecen. In order to have representative results about the species, 3 genotypes (Prestomech $F_{1}, U G 989 F_{1}$, UG1122713 $\left.F_{l}\right)$ were evaluated. The planting date was 3 of May 2018.

The harvesting was two-threaded. The first date was 27 of July 2018. This time the following physical 
parameters were evaluated - fruit shape index (length/diameter), firmness $\left(\mathrm{kg} \mathrm{cm}^{-2}\right)$, water-soluble dry matter content (Brix\%) and weight of the berries (g). The second harvest was on the 15 of August 2018. At this time, rheological evaluations of berry were realised which means the skin resistance measurement (Bioyield point) $(\mathrm{g})$, and the flesh firmness.

The rheological evaluations were performed with a TA.XTplus Texture Analyser instrument, P/2N needle probe in the Food Science Institute, University of Debrecen.

\section{RESULTS AND DISCUSSION}

\section{Fruit shape index}

The fruit shape index is the length of the berry divided by its diameter. When the result equals to 1 , the berry is spherical. However, result $>1$ means the berry is oval, otherwise $<1$ means the berry is flat.

For mechanical harvest, the best shape is oval, with a fruit shape index less than 2.0. The evaluated genotypes' fruit shape index is shown in Figure 1.

Figure 1: Fruit shape index of the evaluated tomato genotypes (Debrecen, 2018)

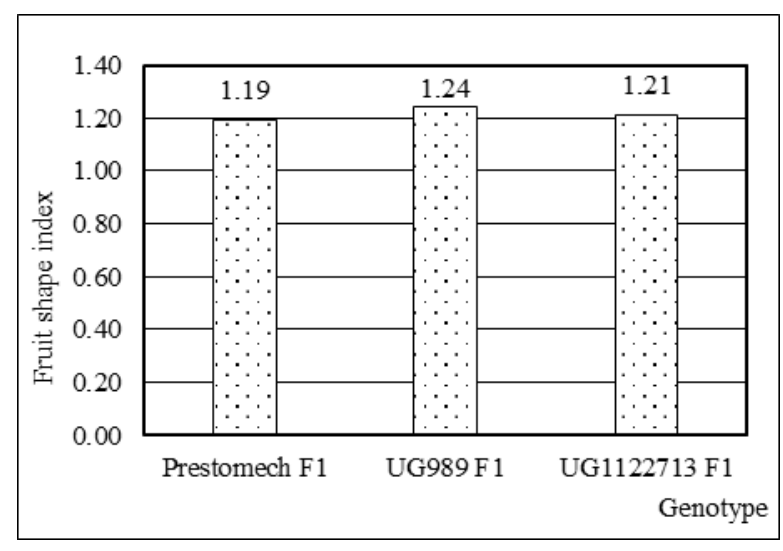

According to the obtained results, all examined genotypes met the requirements. Even the Prestomech $F_{l}$, which had the smallest value, fulfils the requirements of the industry.

\section{Weight of the berries}

Individual berry weight plays a major role in mechanical harvest as it is closely related to the size of the berries. During mechanical harvest, the unified berry size is favourable. It most easily can be accomplished by using a genotype of almost the same berry weight. The evaluated genotypes berry weight is shown is Figure 2.

According to the results, all three genotypes are suitable for mechanical harvest, as all have a pointing error nearly $10 \%$.
Figure 2: Weight of the berries of the evaluated tomato genotypes (Debrecen, 2018

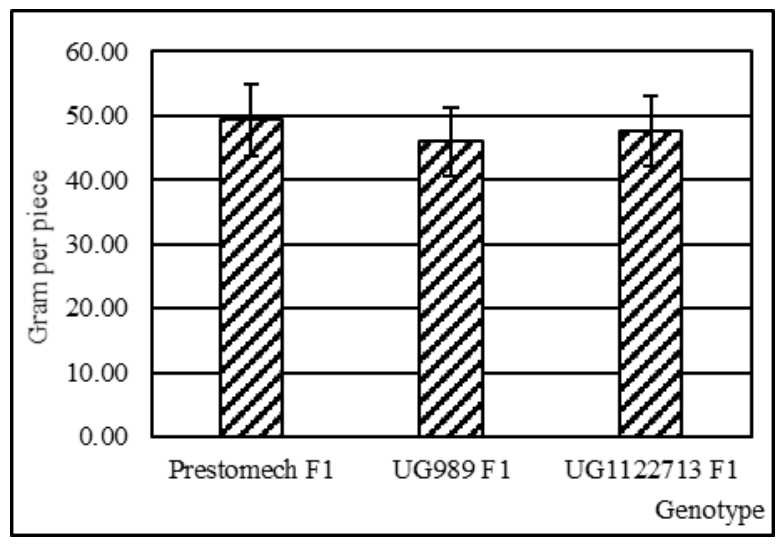

\section{Water-soluble dry matter content (Brix\%)}

To have a proper nutrient content quality for tomato one of the most important parameters is the proper sugar-acid proportion (10:1). This parameter was evaluated after the harvest and the results are shown in Figure 3.

\section{Figure 3: Water-soluble dry matter content (Brix\%) of the} evaluated tomato genotypes (Debrecen, 2018)

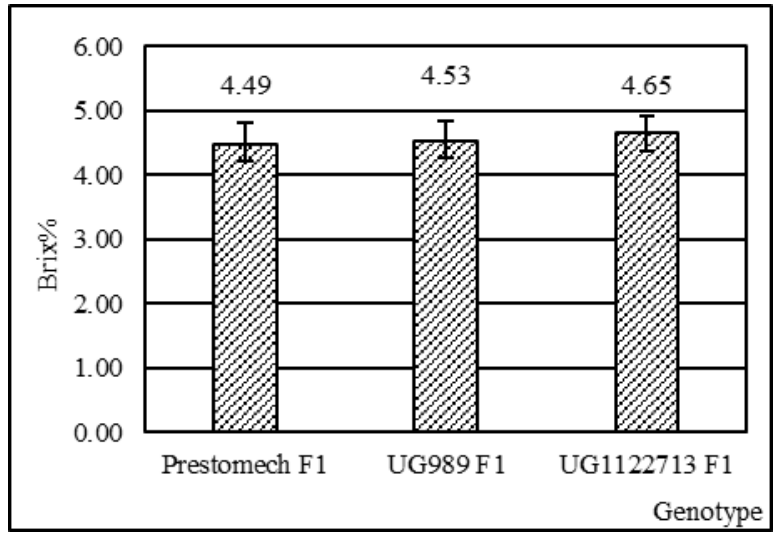

According to the results, the genotypes' Brix $\%$ was between $4.49 \%$ and $4.65 \%$, which fulfils the needs of the industry.

\section{Firmness}

The most important expectation of industrial tomato is the possibility of mechanical harvest. To satisfy this expectation the berry must have a firmness more than $0.90 \mathrm{~kg} \mathrm{~cm}^{-2}$. The results are shown in Figure 4. 
Figure 4: Firmness of the evaluated tomato genotypes (Debrecen, 2018)

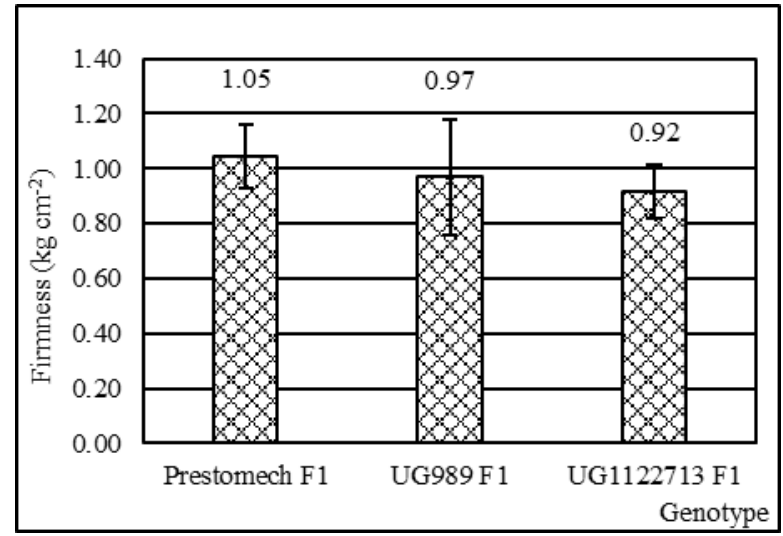

The highest firmness of fruit was detected in the samples of Prestomech $F_{1}$ genotype $\left(1.05 \mathrm{~kg} \mathrm{~cm}^{-2}\right)$. All examined varieties fulfilled the requirements of mechanical harvest with values between $0.92 \mathrm{~kg} \mathrm{~cm}^{-2}$ and $1.05 \mathrm{~kg} \mathrm{~cm}^{-2}$.

\section{Force needed to tear the skin (Bioyield point)}

The bioyield point is the indicative of initial cell rupture in the cellular structure of the material. It shows how much force the berry can tolerate before the flesh splits. The evaluated genotypes' bioyield point is shown in Figure 5.

Figure 5: Bioyield point (g) of the evaluated tomato genotypes (Debrecen, 2018)

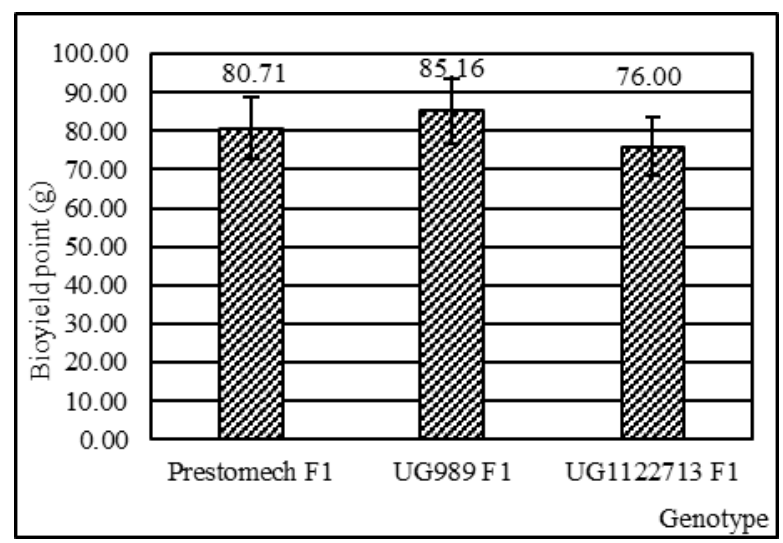

According to the obtained results, the $U G 1122713$ $F_{1}$ has the lower value (76.00). The highest bioyield point belongs to the $U G 989 F_{1}$ genotype (85.16).

\section{Flesh firmness}

Flesh firmness is strongly related to the bioyield point. The results are shown in Figure 6.

As the data obtained, the received results are consistent with the results of the examination of the bioyield point.

Figure 6: Flesh firmness of the evaluated tomato genotypes (Debrecen, 2018)

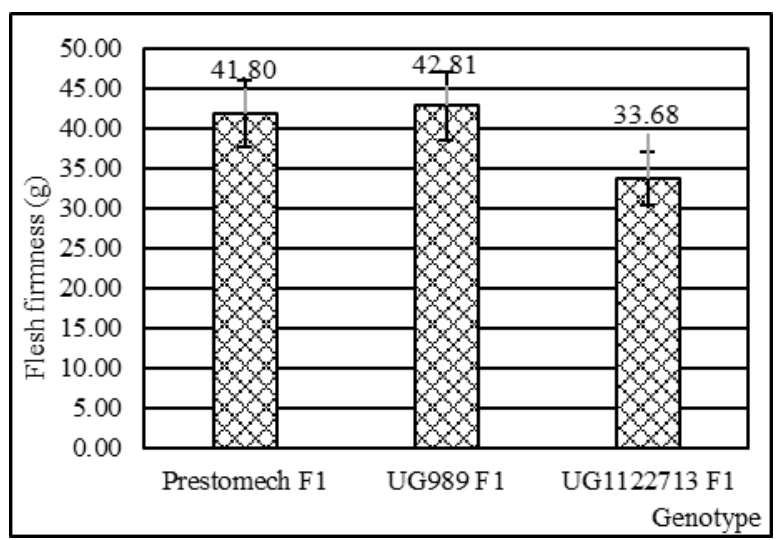

\section{CONCLUSION}

The experiment was carried out between 3 of May 2018 with 2 different harvesting times ( 27 of July and 15 of August). The data are represented in the mean of the three examined genotypes. The aim was to evaluate the physical and rheological parameters to determine the proper genotype for the applied cultivation conditions, and for the farmers to cultivate even in extreme weather conditions. To define these properties, we evaluated the fruit shape index (length/diameter), firmness $\left(\mathrm{kg} \mathrm{cm}^{-2}\right)$, water-soluble dry matter content (Brix\%), weight of the berries, bioyield point $(\mathrm{g})$ and flesh firmness $(\mathrm{g})$.

According to the results, we can conclude that based on the obtained data the UG989 $F_{1}$ hybrid was the most proper for the applied cultivation conditions. This genotype can be recommended for the farmers even in extreme weather conditions.

\section{ACKNOWLEDGMENTS}

This study was supported by the EFOP-3.6.3-VEKOP16-2017-00008.

\section{REFERENCES}

Arana, I.-Jarén, C.-Arazuri, S. (2004): Apple mealiness detection by non-destructive mechanical impact. Journal of Food Engineering. 62. 399-408.

Arazuri, S.-Jarén, C.-Arana, J. I.-Pérez de Ciriza, J. J. (2006): Influence of mechanical harvest on the physical properties of processing tomato (Lycopersicon esculentum Mill.). Journal of Food Engineering. 80. 190-198.
Calvo, M. (1996): Calidad de la producción agraria. Agricultura Sostenible. 577-588.

Catala, M. S.-Cuartero, J.-Palomares, G.-Nuez, F. (1982): Punción $\mathrm{y}$ penetración del fruto de tomate como medidas de su capacidad de agrietamiento. In IV Jornadas de selección y mejora de tomate ypimiento, Zaragoza, Spain

FAO (2018): http://www.fao.org/faostat/en/\#data/QC 
Helyes, L. (1999): A paradicsom és termesztése. SYCA Szakkönyvszolgálat. 233.

Jarén, C.-García, E. (2002): Using non destructive impact testing for sorting fruits. Journal of Food Engineering. 52. 89-95.

KSH (2018): http://www.ksh.hu/docs/hun/xftp/gyor/vet/vet1806.pdf Peris, J. (1983): La calidad de las frutas y hortalizas. La textura como factor de calidad. Metodos e instrumentos para su medida. Agrícola Vergel, 2, 59-64.

Plocharski, W. J.-Konopacka, D.-Zwierz, J. (2000): Comparison of Magness-Taylor's Pressure Test with Mechanical, NonDestructive Methods of Apple and Pear Firmness Measurements. International Agrophysics 14. 311-318.

Rimóczi I. (2018): Százezer tonna ipari paradicsom. Kertészet és Szőlészet.67. évf. 38. sz. 6-9.
Ruiz, M.-Chen, P. (1990): Los productos agrícolas. Evaluación cualitativa y clasificación. Máquinas y Tractores, 2, 82-87.

Vursavus, K. K.-Kesilmis, Z. (2016): Modeling of impact parameters for nondestruvtive evaluation of firmness of greenhouse tomatoes. Agronomy Research. Vol. 14, Special Issue II. 1498-1508.

Wu, T.-Abbott, J. A. (2001): Firmness and force relaxation characteristics of tomatoes stored intact or as slices. Postharvest Biology and Technology. 24. 59-68.

I1: https://magyaridok.hu/gazdasag/tobb-ipari-paradicsom-teremiden-3048904/ 